\title{
EFFECT OF SELENIUM SUPPLEMENTATION ON TWINNING INDUCTION IN BARKI EWES
}

\author{
HOWIDA M.A. ABD-EL-RAHMAN ${ }^{1}$ and MAHA A. IBRAHIM ${ }^{2}$ \\ ${ }^{1}$ Field Investigation Department, Animal Reproduction, Research Institute (ARRI), Giza, Egypt \\ ${ }^{2}$ Biology of Reproduction Department, Animal Reproduction, Research Institute (ARRI), Giza, Egypt
}

Received: 29 May 2018; Accepted: 30 July 2018

\begin{abstract}
This study aimed to evaluate selenium supplementation effect on induction of twinning of Barki ewes by using two different doses of PMSG in estrus synchronization program during the breeding season. For the experiment, 28 ewes were randomly divided into four groups, 7 ewes in each group, all ewes were treated with intra-vaginal sponges, containing $60 \mathrm{mg}$ medroxy progesterone acetate for 14 days, immediately after sponge withdrawal, PMSG hormone at a doses of 250 IU in groups I, II and 750 IU in groups III and IV were administered intramuscularly. Selenium (Se) levels were $0.05 \mathrm{mg} / \mathrm{kg}$ diet DM (without supplementation) for groups I and III and $0.2 \mathrm{mg} / \mathrm{kg}$ diet DM for groups II and IV (Se supplementation). The pregnancy and barren rates for groups I, II, III and IV were $(57.14 \%, 100 \%, 71.43 \%$ and $85.71 \%)$ and $(42.86 \%, 0.0 \%, 28.57 \%$ and $14.29 \%)$, respectively $(\mathrm{P}<0.01)$. At the same time, the twinning rate was $(0 \%, 71.43 \%, 42.86 \%$ and $71.43 \%)$, and the lambing rate was $(57.14 \%, 100 \%, 71.43 \%$ and $85.71 \%)$ for the four groups respectively $(\mathrm{P}<0.01)$. Meanwhile, the fecundity rate for the same groups was $(57.14 \%, 171.43 \%, 114.28 \%$ and $157.14 \%)$, respectively. Decreasing PMSG dose with Se supplementation appear to be a most appropriate program for induction of twinning and increasing of fertility and fecundity rates.
\end{abstract}

Key wards: selenium, twinning rate, fertility, fecundity, ewes.

\section{INTRODUCTION}

Methods to improve reproduction in sheep often aim to increase the proportion of ewes having multiple ovulations, and thereby increase lambing percentage (Wilkins, 1997). Increasing rate of fecundity in sheep offers the best opportunity to increase the efficiency of lamb meat production (Turk et al., 2008). Administration of gonadotropins such as human chorionic gonadotropin (hCG) (Evans, 2003), pregnant mare serum gonadotropin (PMSG) (Lamrani et al., 2008), follicle stimulating hormones (FSH) and mixed gonadotropin preparations (Kinghts et al., 2003) after stopping progestogens treatment, causes increasing of ovulation and lambing rate. Between all endocrine approaches to increase twinning rate, administration of PMSG is more usual than others. Moreover, it was reported that PMSG can increase pregnancy and twinning rates in breeds characterized by low litter size (Boscos et al., 2002). PMSG has a high affinity with both follicle stimulating hormone (FSH) and luteinizing hormone $(\mathrm{LH})$ receptors in the

Corresponding author: Dr. MAHA A. IBRAHIM

E-mail address: maha_doctor2013@yahoo.com

Present address: Biology of Reproduction Department, Animal

Reproduction, Research Institute (ARRI), Giza, Egypt ovaries and has long-lasting LH- and FSH-like effects on the follicle. It enhances the entry rate of small and medium follicles into larger follicles and it may prevent the occurrence of natural follicular atresia (Mandiki et al., 2000). However, there are many factors influence the efficiency of PMSG, including the dose and administration time (Timurkan and Yildiz, 2005). It has been found that using of low dose of PMSG is less effective and did not increase fertility or prolificacy (Romano et al., 1996 and Akoz et al., 2006), and the using of high dose of PMSG induced multiple ovulations and improved the fertility and proliferation (Koyuncu et al., 2001 and Timurkan and Yildiz, 2005). Meanwhile, as hormonal treatment is still expensive so that the use of high dose tends to elevate the costs for subsistence farmer, therefore the efficiency is difficult to achieve, as the major problem that faces the farmer in sheep reproduction management, is the looking for reproductive techniques, which could help the farmer, and decreases the cost of production. So that this problem motivates the researchers to find an alternative by using a lesser dose of gonadotropin, that implies a reduction in cost, without any reduction in fertility and proliferation.

Selenium is a micro mineral that is a part of the enzyme glutathione peroxidase (GSH-Px), which is 
an important antioxidant that inactivates free radicals and that protects cells from the damage caused by lipid peroxidation and since protects the oocyte membrane against oxidative damage (Luberda, 2005; Livingston et al., 2009). Se deficiency plays a role in numerous economically important livestock problems that include impaired fertility, abortion, retained placenta and neonatal weakness (McDowell et al., 1996). Single injection of Se before mating and lambing significantly affects oestrous, fertility, and lamb daily weight gain (Gabryszuk and Klewiec, 2002). Also, Malecki et al. (2002) stated that Se supplementation to ewes before mating improved fertility, prolificacy and the number of twins when compared with the control.

The objective of this study is to determine the impact of Se supplementation ( 0.05 or $0.2 \mathrm{mg} / \mathrm{kg}$ diet DM) on reproductive performance (pregnancy rate; twinning rate; lambing rate as well as fecundity rate) of adult ewes at a synchronized estrus in relation to two different doses of PMSG (high; 750 IU \& low; 250 IU). And study the capability of combination between low dose of PMSG (250 IU) and Se supplementation in terms of increasing the pregnancy and twining rates in Barki ewes with a minimum cost.

\section{MATERIALS AND METHODS}

Animals and study site:

Twenty-eight multiparous clinically healthy Barki ewes weighing (50-60 kg) reared in a private farm were used in this study; the ewes were run with vasectomized rams and ascertained to be cyclic before the onset of the experiment.

\section{Animal housing and feeding:}

Each group was kept in a separate, well-ventilated shed, under condition of natural day light and temperature. All ewes were proved to be clinically healthy and free from external and internal parasites. All groups fed a standard total mixed ration according to NRC (1985). Feed composition of the used total mixed ration as shown in table (1). The ration was analyzed for Dry matter, Crude protein, Ash, Ether extract, NDF and ADF according to A.O.A.C. (1990).

Table 1: Feed composition and proximate analysis of the used diets (total mixed rations) for ewes under experiment:

\begin{tabular}{|c|c|c|c|c|}
\hline \multirow[t]{2}{*}{ Ingredient } & \multicolumn{2}{|c|}{$\begin{array}{c}\text { Diet used during the first } 4 \text { months } \\
\text { of pregnancy } \\
(\% \text { As- fed basis })\end{array}$} & \multicolumn{2}{|c|}{$\begin{array}{c}\text { Diet used during the last } 4 \\
\text { weeks of pregnancy } \\
\text { (\% As- fed basis) } \\
\end{array}$} \\
\hline & $\begin{array}{c}\text { Without Se } \\
\text { supplementation }\end{array}$ & $\begin{array}{c}\text { With Se } \\
\text { supplementation }\end{array}$ & $\begin{array}{c}\text { Without Se } \\
\text { supplementation }\end{array}$ & $\begin{array}{c}\text { With Se } \\
\text { supplementation }\end{array}$ \\
\hline Yellow Corn & 4.00 & 4.00 & - & - \\
\hline Soybean meal $(44 \%)$ & 3.00 & 3.00 & 1.00 & 1.00 \\
\hline Wheat bran & 4.5 & 4.5 & 16.00 & 16.00 \\
\hline Corn silage & 82.1 & 82.1 & 61.00 & 61.00 \\
\hline Barseem straw & 4.00 & 4.00 & 21 & 21 \\
\hline \multicolumn{5}{|l|}{ Mineral \&Vitamin mixture: } \\
\hline Mineral \&Vitamin mixture(1)* & 0.1 & - & 0.1 & - \\
\hline $\begin{array}{l}\text { Mineral \&Vitamin mixture } \\
\text { with Se (2)** }\end{array}$ & - & 0.1 & - & 0.1 \\
\hline \multicolumn{5}{|l|}{ Proximate analysis (on DM basis): } \\
\hline Dry matter (\%) & 52.62 & 52.62 & 40.67 & 40.67 \\
\hline Crude protein $(\%)$ & 14.03 & 14.03 & 10.60 & 10.60 \\
\hline $\begin{array}{l}\text { Metabolizable energy (Mcal / } \\
\text { kg) }\end{array}$ & 2.50 & 2.50 & 2.10 & 2.10 \\
\hline Selenium (ppm) & 0.05 & 0.20 & $\mathbf{0 . 0 5}$ & 0.20 \\
\hline \multicolumn{5}{|l|}{ Dry matter intake (kg / head/day): } \\
\hline Dry matter (kg) & \multicolumn{2}{|c|}{$2.5 \mathrm{~kg}$} & \multicolumn{2}{|c|}{$1.8 \mathrm{~kg}$} \\
\hline
\end{tabular}

* Each $1 \mathrm{Kg}$ of mineral \& Vitamin mixture (1) containing $2.5 \mathrm{~g}$ Zinc, $20.0 \mathrm{~g}$ manganese, $2.00 \mathrm{~g}$ copper, $50.0 \mathrm{~g}$ iron, $0.25 \mathrm{~g}$ Iodine, $0.05 \mathrm{~g}$ Cobalt, $4000000 \mathrm{IU}$ Vitamin A, $1000000 \mathrm{IU}$ Vitamin D, and $15.0 \mathrm{~g}$ vitamin E.

** Each $1.0 \mathrm{~kg}$ of mineral and Vitamin (2) containing nutrient concentration as (1) in addition to $0.075 \mathrm{~g}$ Selenium. 
Estrous synchronization and PMSG treatment:

All ewes were received intravaginal sponges impregnated with $60 \mathrm{mg}$ medroxy progesterone acetate $\left(\right.$ Veramex ${ }^{\circledR}$, Upjohn Company) for 14 days. At the day of sponges' withdrawal, ewes were randomly divided into four groups (GP) and an intramuscular administration of pregnant mare serum gonadotrophin, PMSG (Folligon, Intervet) as follow:

- The first group, (GPI; $\mathrm{n}=7$ ) ewes were injected with 250 IU PMSG / head without selenium supplementation.

- The second group, (GPII; $\mathrm{n}=7$ ) ewes were injected with 250 IU PMSG / head with selenium supplementation (selenium level $0.2 \mathrm{mg} / \mathrm{kg}$ diet DM).

- $\quad$ The third group, GPIII; $n=7$ ) ewes were injected with 750 IU PMSG / head without selenium supplementation.

- The fourth group, (GPIV; $\mathrm{n}=7)$ ewes were injected with 750 IU PMSG / head with selenium supplementation (selenium level $0.2 \mathrm{mg} / \mathrm{kg}$ diet DM).

\section{Estrus detection and mating:}

Two fertile rams were introduced to all ewes in the four groups twice daily, just after sponge withdrawal, and left with them for natural mating for 2 hours each time.

\section{Reproductive performance:}

One month after the insemination, conception rates of animals of the four groups were checked by ultrasonography, using a real time B-mode (Veston, Kontron France) equipped with 6.5 MHZ probe. Lambing was determined by daily observation and identification of ewes in small lambing plots. The numbers of lambs born per ewe were recorded during lambing.

\section{Data analysis:}

Data were subjected to statistical analysis by Microstate copy right (c) 1984; Eco soft, Inc. employing a completely randomized design according to Snedecor and Cochran (1982).

\section{Measured traits throughout the experimental period:}

Fertility was monitored in terms of pregnancy rate, twinning rate, lambing rate, as well as fecundity rate
(Hartley. 1963, Zeleke et al., 2005, Kridli et al., 2006 Ozyurtlz et al., 2011).

Pregnancy rate $=$ number of pregnant ewes $/$ number of mated ewes x 100.

Barren rate = number of non-pregnant ewes / number of mated ewes x 100.

Twinning rate $=$ number of pregnant ewes bearing twins/number of mated ewes x 100.

Lambing rate $=$ number of lambing ewes / number of mated ewes x 100 .

Fecundity rate $=$ number of lambs born (alive) $/$ number of ewes mated x 100 .

\section{RESULTS}

No intravaginal sponges were lost during the trial and none of the ewes showed oestrous while the intravaginal sponges were in place.

The effects of selenium supplementation and PMSG dose on reproductive performance are shown in Figures (1-5).

The results indicated that the pregnancy rate was significantly higher $(\mathrm{p}<0.05)$ in group II than in group I $(100 \%$ vs $57.14 \%)$ and tend to be significant $(\mathrm{p}<0.06)$ than in group III $(100 \%$ vs $71.43 \%)$, meanwhile it was non-significantly higher than in group IV (100\% vs $85.71 \%)$. The twinning rate was significantly higher $(\mathrm{p}<0.05)$ in group II than in group I $(71.43 \%$ vs $0.0 \%)$, meanwhile it was nonsignificantly higher than in group III $(71.43 \%$ vs $42.86 \%)$ and group IV (71.43\% vs $71.43 \%)$. The barren rate was significantly lower $(\mathrm{p}<0.05)$ in group II than in groups I $(0.0 \%$ vs $42.86 \%)$ and III $(0.0 \%$ vs $28.57 \%$ ), meanwhile the decrease was non-significant than group IV $(0.0 \%$ vs $14.29 \%)$. The fecundity rate was significantly higher $(\mathrm{p}<0.05)$ in group II than in groups I (171.43\% vs $100 \%)$ and III (171.43\% vs $114.28 \%$ ), meanwhile it was non-significantly higher than group IV (171.43\% vs $157.14 \%)$. The lambing rate was significantly higher $(\mathrm{p}<0.05)$ in group II than group I (100\% vs $57.14 \%$ ) and tend to be significant $(p<0.06)$ than in group III $(100 \%$ vs $71.43 \%)$, meanwhile it was non-significantly higher than group IV $(100 \%$ vs $85.71 \%)$. Also our results showed that pregnancy and lambing rates were tend to be significant $(\mathrm{p}<0.1)$ in group IV than in group I (85.71\% vs $57.14 \%)$. 


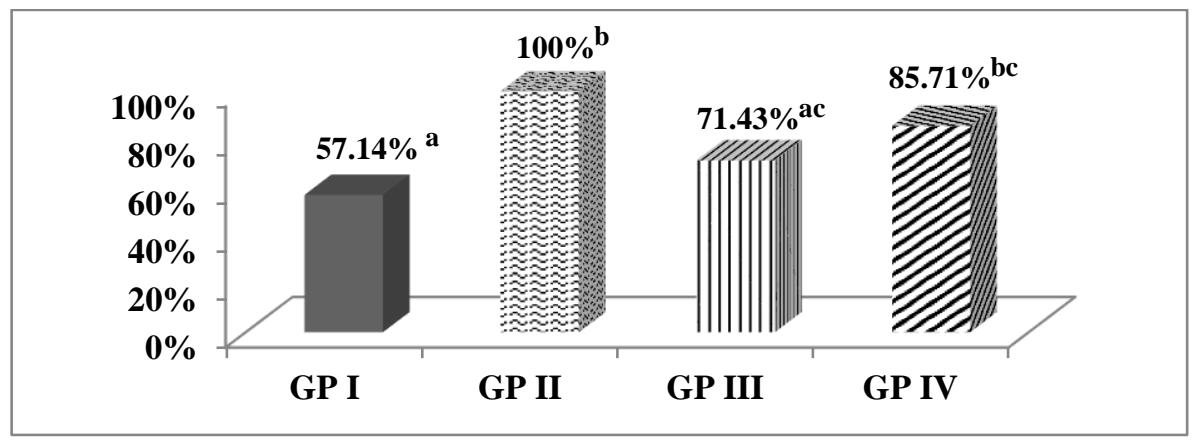

GP: group, significance at $(\mathrm{P}<0.05)$

Figure 1: Pregnancy rate of ewes $(n=7)$ as affected by Se and PMSG (GP I) 250 IU PMSG without Se, (GP II) 250 IU PMSG with Se, (GP III) 750 IU PMSG without Se and (GP IV) 750 IU PMSG with Se.

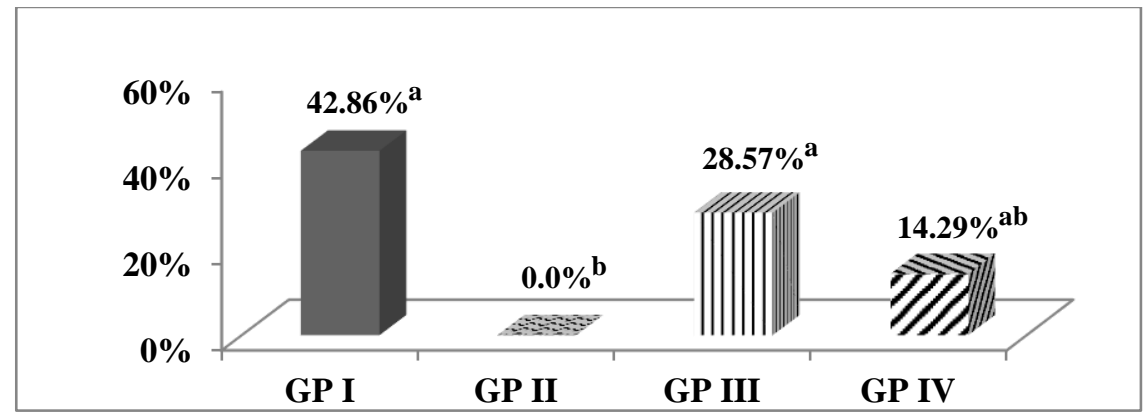

GP: group, significance at $(\mathrm{P}<0.05)$

Figure 2: Barren rate of ewes (n=7) as affected by Se and PMSG (GP I) 250 IU PMSG without Se, (GP II) 250 IU PMSG with Se, (GP III) 750 IU PMSG without Se and (GP IV) 750 IU PMSG with Se.

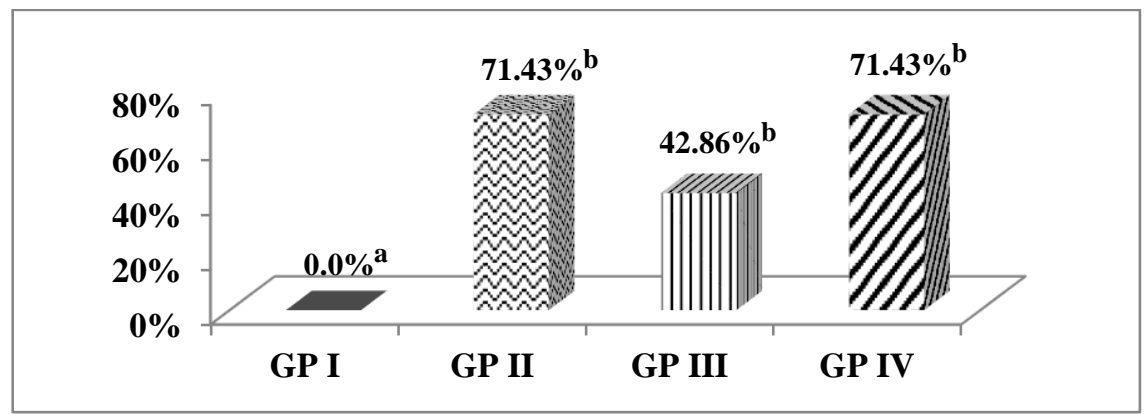

GP: group, significance at $(\mathrm{P}<0.05)$

Figure 3: Twinning rate of ewes $(n=7)$ as affected by Se and PMSG (GP I) 250 IU PMSG without Se, (GP II) 250 IU PMSG with Se, (GP III) 750 IU PMSG without Se and (GP IV) 750 IU PMSG with Se.

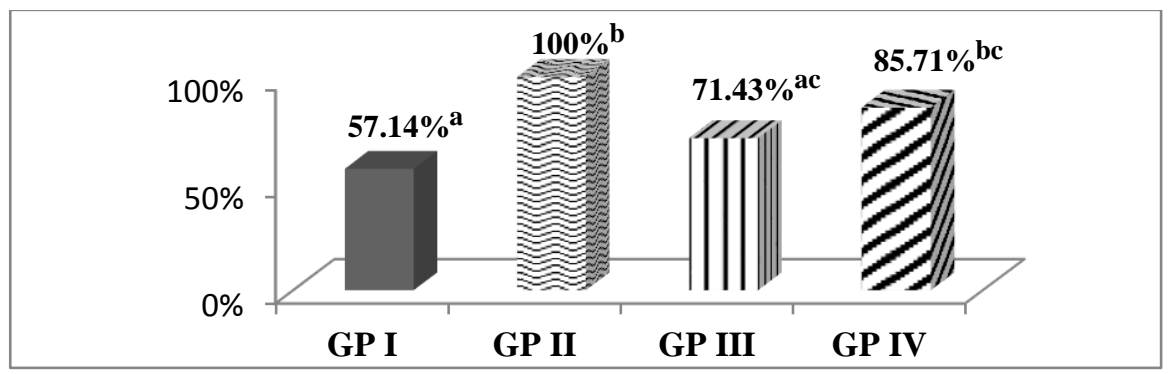

GP: group, significance at $(\mathrm{P}<0.05)$

Figure 4: lambing rate of ewes (n=7) as affected by Se and PMSG, (GP I) 250 IU PMSG without Se, (GP II) 250 IU PMSG with Se, (GP III) 750 IU PMSG without Se and (GP IV) 750 IU PMSG with Se. 


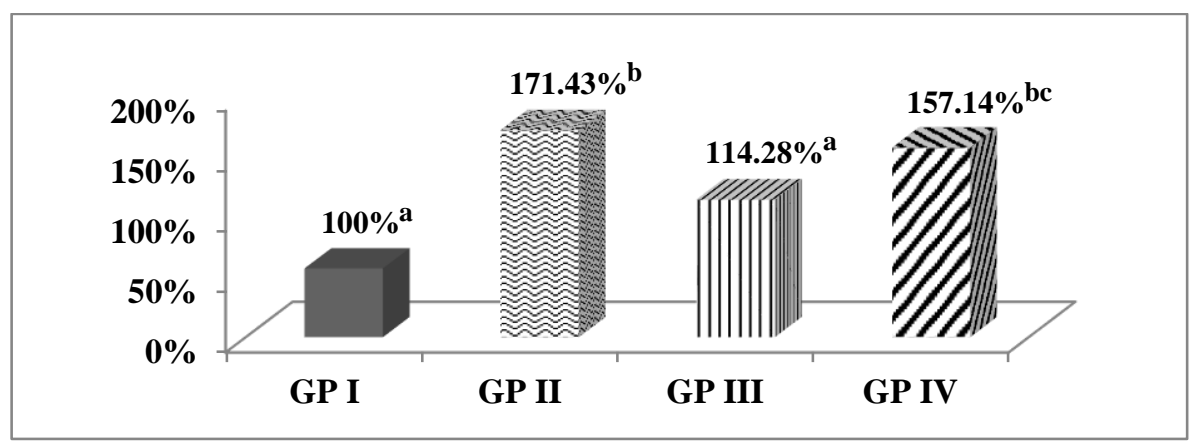

GP: group, significance at $(\mathrm{P}<0.05)$

Figure 5: Fecundity rate of ewes $(n=7)$ as affected by Se and PMSG (GP I) 250 IU PMSG without Se, (GP II) 250 IU PMSG with Se, (GP III) 750 IU PMSG without Se and (GP IV) 750 IU PMSG with Se.

\section{DISCUSSION}

Increasing sheep productivity by increasing twinning rate, lambing rate, litter size and fecundity is considered as an important factor in the development of Barki sheep production in Egypt. On the other hand, increasing litter size and fecundity rates in Barki sheep offer the best opportunity to increase the efficiency of lamb meat production.

Regarding to PMSG dose without Se supplementation, results in the present study indicated that, the dose of 750 IU (GP III) was found to be more effective $(71.43 \%, 28.57 \% 42.86 \%, 71.43 \%$ and $114.28 \%$ ) as compared with 250 IU (GP I) $(57.14 \%$, $42.86 \%, 0,0 \%, 57.14 \%$ and $100 \%$ ) in pregnancy rate, barren rate, twinning rate, lambing rate as well as fecundity rate especially in twinning rate which was significantly higher $(\mathrm{P}<0.05)$ in $(\mathrm{GP}$ III) than that in (GP I). These results were in agreement with the previous findings of Askin (1982) who found that the pregnancy rate were found as $72.4 \%$, multiple birth rate as $40 \%$ and litter size as 1.48 in the group treated with 750 IU PMSG, and Abdel-Mageed (2006) who reported that using one dose of PMSG (750 IU) significantly increased the ovulation rate and litter size but it had an insignificant effect on conception rate.

Gonadotrotropins are used to induce superovulation in sheep (Evans, 2003). So the injection of PMSG immediately after progestagen sponge removal produce an increase in the ovulation rate (Maxwell et al., 1993 and Romano et al., 1996). Also, Kridli and Al-Khetib (2006) reported that gonadotrotropins improve follicular development, increase ovulation rate and multiple births in ewes.

Improvement of reproductive performance of ewes as a result of PMSG injection may be due to the positive action of FSH in PMSG on ovarian functions. PMSG has primarily long acting FSH activity (Squires,
2003), it enhances the entry rate of small and medium follicles into larger follicles and it may prevent the occurrence of natural follicular atresia (Mandiki et al., 2000), also it stimulates estradiol and progesterone secretion. In consequence, it stimulates the number of follicles, which lead to more follicular development and increase ovulation and pregnancy rates and hence enhance the twinning rate (Dogan and Nur, 2006 and Sirjani et al., 2011; Rensis and López-Gatius, 2014), which leads to acceptable results on response to oestrous, fertility, and fecundity with high dose of PMSG, and can be successfully used for estrus induction and superovulation in sheep. Meanwhile, the low dose was less effective and did not increase fertility or prolificacy which was in agreement with Romano et al. (1996) who reported that, PMSG at 250 IU did not increase the fertility or prolificacy rates in ewes during the breeding season, and Akoz et al. (2006) who reported that 300 IU of PMSG did not sufficiently $(42.86 \%)$ increase the multiple birth rates. That has been suggested that low PMSG doses were not sufficient to stimulate additional follicular development in ewes (Romano et al., 1996), consequently reduced response to fertility or prolificacy rates. Meanwhile, it was reported that pregnancy rate in Hamadani or Akkaraman ewes which superovulated with 750 IU of PMSG was 100\% (Timurkan and Yildiz, 2005 and Akoz et al., 2006). Also, Koyuncu et al. (2001) found that when Kivircik ewes superovulated with different doses of PMSG during breeding season prolificacy rate was $196 \%$ in 700 IU group. These rates were higher than this study obtained by using 750 IU of PMSG. This difference may be explained by the influence of breed differences and some management factors on response to the treatment protocol, Karagiannidis et al. (2001) who reported that response to the different PMSG doses among various breeds was different.

Concerning the effect of the PMSG dose with Se supplementation, data obtained in this study indicated that pregnancy rate, twinning rate, lambing rate, as 
well as fecundity rate were non-significantly higher in (GP II) $(100 \%, 71.43 \%, 100 \%$, and $1171.43 \%)$ than that in (GP IV) $(85.71 \%, 71.43 \%, 85.71 \%$, and $157.14 \%$ ), and significantly higher than that in groups without Se supplementation, GP I (in all parameters) and GP III (in fecundity rate only and tend to be significantly higher in pregnancy and lambing rate), these findings were in agreement with several authors who observed a positive effect of Se administration on reproductive performance of sheep, Munoz et al. (2009) reported a higher conception rate, fecundity rate and a lower abortion rate in ewes treated with $\mathrm{Se}$ before mating. Koyuncu and Yerlikaya (2007) found that $\mathrm{Se}$ injection to Merino ewes significantly increased estrus response and fecundity rate $(100 \%$ and $131 \%$, respectively), Also, Balicka-Ramisz et al. (2006) found that Se administration prior to mating enhanced herd's reproductive success and increased the litter size by 0.38 lamb per treated ewe as compared with the control. Also, Hemingway (2003) reported that the ewes fecundity rate considerably dependent on the feed Se level. Muñoz et al. (2009) stated that premating Se treated ewes had a higher conception rates; lower abortion rates and reared $9 \%$ more lambs than the control. Se supplementation to ewes grazing in pastures with low Se and high estrogen levels increased the conception rate, from 49 to $76 \%$ (McDowell, 1997). Also, our obtained results showed that the numbers of barren ewes were lower in PMSG plus Se supplemented groups than in PMSG without Se supplementation groups, particularly in group II (250 IU PMSG plus Se) which had no barren ewes. This finding was previously supported by Scales, (1974) who reported that premating dose of $5.0 \mathrm{mg}$ Se reduced the number of barren merino ewes by $15 \%$. These results indicated that $\mathrm{Se}$ supplementation has a PMSG-sparing effect as the optimum dose of PMSG which give optimum reproductive performance will be reduced in $\mathrm{Se}$ supplemented groups. These positive effects of Se supplementation on fertility of treated females may be attributed to the increase of their serum GSH-Px level by Se supplementation, Wittwer et al. (2002), who found a positive correlation between the amounts of Se ingested by the animal and its serum GSH-Px level. And according to Eppig (1996), Krisher and Bavister (1998) and Livingston et al. (2009), stated that GSH-Px proved to be important in the maturation process of oocytes, by involving in the synthesis of biochemical components, phosphorylation of proteins and the activation of specific metabolic pathways. Also Uhm et al. (2007) stated that Se guarantees adequate biosynthesis of selonoprotein, protecting the embryos' cells against oxidants and apoptosis. In relation to selonoprotein, we can cite the study of Livingston et al. (2009), who emphasized the importance of Se in sheep reproduction in vivo, when assessing the quality of oocytes matured in vivo. On the same hand, in vitro oocyte maturation and fertilization, Hirotada et al. (2017) stated that Se overcame the undesirable oxidative stress produced by hydrogen peroxide, increased blastocyst formation and enhanced the development of pre-implanted mouse embryo of mouse blastocysts cultured in the presence of Se. Also, Moraes et al. (2012) stated that dairy Jersey cows' diet supplemented with Se rendered the production of higher quantity of grade 1 oocytes and greater production of embryos in the process of in vitro fertilization.

The enhanced response observed in low dose PMSG 250 IU group with Se supplementation (GP II) was not found in Se-supplemented group given high dose 750 IU of PMSG (GP IV) or in groups given similar low or high doses of PMSG (250 IU or 750 IU) but without Se supplementation. Finally, our results showed that the best reproductive results were achieved by the ewes of group II (250 IU PMSG plus Se) (pregnancy rate $100 \%$, twinning rate $71.43 \%$, lambing rate $100 \%$, as well as fecundity rate $171.43 \%$ ), and also, reproductive results achieved by ewes of group IV (750 IU PMSG plus Se) were also acceptable (pregnancy rate $85.71 \%$, twinning rate $71.43 \%$, lambing rate $85.71 \%$, as well as fecundity rate $157.14 \%$ ). As the addition of high dose PMSG to an estrus synchronization program for induction of twinning tend to elevate costs, our data show a clear advantage of decreasing its dose as low as 250 IU/ewe with Se supplementation for induction of twinning and increasing of fertility and fecundity rates and appeared to be a most appropriate program because it combines simplicity and a lesser dose of gonadotropin, which also implies a reduction in cost, without reducing embryo production. However, from the practical point of view, selenium supplementation could be preferred and effectively applied with low dose of PMSG to the estrus synchronization program for induction of twinning as it showed the lowest cost.

\section{REFERENCE}

Abdel-Mageed, I.I. (2006): Economic evaluation of lamb production in Rahmani sheep under two regimes for supper-ovulation, $\mathrm{Ph}$. D Thesis., Fac. of Agric., Cairo University.

Akoz, M.; Bulbul, M.; Ataman, B. and Dere, S. (2006): Induction of multiple births in Akkaraman cross-breed synchronized with short duration and different doses of progesterone treatment combined with PMSG outside the breeding season. Bulletin of the Veterinary Institute in Pulawy. 50: 97-100.

AOAC (1990): Association of Official Analytical Chemists. (1990): Official methods of analysis. 15th ed. Arlington, VA.

Askin, Y. (1982): Oestrus Synchronization and Opportunities of Supervision of Reproductive Performance in Akkaraman and Anatolian Merino Sheep Using Exogenous Hormone. 
Ankara University Faculty of Agriculture. Ankara. Sdu. edu.tr/4UZBK/HYB/4UZBK _ 022pdf.

Balicka-Ramisz, A.; Pilarzyk, B.; Ramisz, A. and Wieczorek, M. (2006): Effects of selenium administration on blood serum Se content and on selected reproductive characteristics of sheep. Arch Tierz 49: 176-80.

Boscos, C.M.; Samartzi, F.C.; Dellid, S.; Rogge, A.; Stefanakis, A. and Krambovitis, E. (2002): Use of progestagen-gonadotrophin treatment in estrus synchronization of sheep. Theriogenology; 58: 1261-1272.

Dogan, I. and Nur, Z. (2006): Different estrous induction methods during the non-breeding season in Kivircik ewes. Vet Med-Czech 51: 133-138

Eppig, J.J. (1996): Coordination of nuclear and cytoplasmic maturation in eutherian mammals. Reprod. Fertil. Dev., 8: 485-489.

Evans, A.C.O. (2003): Ovarian follicle growth and consequences for fertility in sheep. Journal of Animal and Veterinary Advances. 78: 289306.

Gabryszuk, M. and Klewiec, J. (2002): Effect of injecting 2-and 3-year-old ewes with selenium and selenium-vitamin $\mathrm{E}$ on reproduction and rearing of lamb. Small Rumin. Res. 43, (2): $127-132$.

Hartley W.J. (1963): Selenium and ewe fertility; Syaney University Rural Veterinary Centre, Camden. New-Zealand Society of Animal Production; online archive.

Hemingway, R.G. (2003): The influences of dietary intakes and supplementation with selenium and vitamin $\mathrm{E}$ on reproduction diseases and reproductive efficiency in cattle and sheep. Veterinary Research Communication 27: 159174.

Hirotada, T.; Miah, A.G. and Salma, U. (2017): Effect of Selenium and Vitamin E on Development and Viability of Preimplanted Mouse Embryo. Dairy and Vet Sci. J. 2(5).

Karagiannidis, A.; Varsakeli, S.; Karatzas, G. and Brozos, C. (2001): Effect of time of artificial insemination on fertility of progestagen and PMSG treated indigenous Greek ewes, during non-breeding season. Small Ruminant Research. 39: 67-71.

Kinghts, M.; Baptiste, Q.S.; Dixon, A.B.; Pate, J.I.; Marsh, D.J.; In-sheep, EK. and Lewis, P.E. (2003): Effects of a dosage of FSH, vehicle and time of treatment on ovulation rate and prolificacy in ewes during the anestrous season. Small Ruminant Research. 50: 1-9.

Koyuncu, M.; Uzun, S.K. and Sengül, L. (2001): Kıvırcık koyunların da progesterone ve farklı dozda PMSG kullanımının kızgınlık denetimi ve döl verimini arttı rma olanakları. Turkish
Journal of Veterinary and Animal Sciences. 25: 971-974.

Koyuncu, M. and Yerlikaya, H. (2007): Effect of selenium-vitamin $\mathrm{E}$ injection of ewes on reproduction and growth of their lambs. S. Afr. J. Anim. Sci., 37: 233-236.

Kridli, R.T. and Al-Khetib, S.S. (2006): Reproductive response in ewes treated with ECG or increasing doses of royal jelly. Anim. Reprod. Sci. 92: 75-85.

Kridli, R.T.; Husein, M.Q.; Muhdi, H.A. and AlKhazaleh, J.M. (2006): Reproductive performance of hormonally treated anestrous Awassi ewes. Anim. Reprod. 3, 347-352.

Krisher, R.L. and Bavister, B.D. (1998): Response of oocytes and embryos to the culture environment. Theriogenology, 49: 103-114.

Livingston, T.; Rick, K. and Mackenzie, S. (2009): Glutathione content and antioxidant enzyme expression of in vivo matured sheep oocytes. Anim. Reprod. Sci., 116: 265-273.

Luberda, Z. (2005): The role of glutathione in mammalian gametes. Reprod. Biol., 5: 5-17.

Lamrani, F.; Benyounes, A.; Sulon, J.; Khaldi, G.; Rekik, R.; Bouraoui, B.; Beckers, JF. and Tahar, A. (2008): Effects of repeated use of PMSG on reproductive performances of the ouled djellal ewes. Journal of Animal and Veterinary Advances. 2: 22-30.

Malecki, J.; Malinowski, E.; Supera, K. and BalickaRamisz, A. (2002): Influence of selenium with vitamin $\mathrm{E}$ and cobalt heavy pellets on reproduction and metabolic profiles of ewes. EJPAU 5(2): 1-9.

Mandiki, S.N.; Noel, B.; Bister, J.L.; Peeters, R.; Beerlandt, G.; Decuypere, E.; Visscher, A.; Suess, R.; Kaulfuss, K.H. and Paquay, R. (2000): Pre-ovulatory follicular characteristics and ovulation rates in different breed crosses, carriers or non-carriers of the Booroola or Cambridge fecundity gene. Anim. Reprod. Sci. 63: $77-88$

Maxwell, W.M.C.; Evans, G.; Rhodes, S.L.; Hillard, M.A. and Bindon, B.M. (1993): Fertility of superovulated ewes after intrauterine or oviducal insemination with low numbers of fresh or frozen-thawed spermatozoa. Reprod Fertil Dev. 5: 57-63.

McDowell, L.R. (1997): Minerals for grazing ruminants in tropical regions (3rd Ed). Univ. Of Florida, Gainesville.

McDowell, L.R.; Williams, S.N. and Hidiroglou, N. (1996): Vitamin E supplementation for the ruminants. Anim. Feed Sci. Technol., 60: 273296.

Moraes, G.V.; Azevedo, J.R; Carneiro, T.C.; Cavalieri, F.L.B. Mataveli, M.; Rossi, R.M. and Santos, T.C. (2012): Oocyte aspiration and in vitro embryo production in Jersey cows 
with selenium-supplemented diet. Arq. Bras. Med. Vet. Zootec. 64(4): 787-795.

Muñoz, C.; Carson, A.F.; McCoy, M.A.; Dawson, L.E.; Irwin, D.; Gordon, A.W. and Kilpatrick, DJ. (2009): Effect of supplementation with barium selenite on the fertility, prolificacy and lambing performance of hill sheep. Vet Rec. 28; 164(9): 265-71.

NRC (1985): Nutrient requirements of sheep, $6^{\text {th }}$ ed. National Academy Press, Washington, DC.

Ozyurtlu, N.; Ay Serhan, S.; Kucukaslan, I.; Gungor, $O$. and Aslan, S. (2011): Effect of subsequent two short-term, short-term, and long-term progestagen treatments on fertility of Awassi ewes out of the breeding season. Ankara Univ. Vet. Fak. Derg. 58,105-109.

Rensis De, F. and López-Gatius, F. (2014): Use of equine chorionic gonadotropin to control reproduction of the dairy cow: a review. Reprod Domest. Anim. 49(2): 177-182.

Romano, J.E.; Rodas, E.; Ferreira, A.; Lago, I. and Benech, A. (1996): Effects of progestagen, PMSG and artificial insemination time on fertility and prolificacy in Corriedale ewes. Small. Rum. Res. 23: 157-162.

Scales, G.H. (1974): Reproductive performance of Merino ewes dosed with selenium prior mating. Proc. N.Z. Soc. Anim. Prod., 34: 103113.

Snedecor, G.W. and Cochran, W.G. (1982): Statistical methods. 7th Edition, the Iowa State University Press, Iowa.

Sirjani M.A.; Shahir, M.H.; Kohramand, H. and Shane, A.Z. (2011): Effect gonadotropin releasing hormone $(\mathrm{GnRH})$ treatment on multiple births in Afshari ewes. African J. of Biotechnology, 10 (57): 12358-12362.

Squires, E.J. (2003): Applied Animal Endocrinology. CABI Publishing, CANADA.

Timurkan, H. and Yildiz, H. (2005): Synchronization of oestrus in Hamadani ewes: the use of different PMSG doses. Bulletin of the Veterinary Institute in Pulawy. 49: 311-314.

Turk, G.; Gur, S.; Sonmez, M.; Bozkurt, T.; Aksu, E.H. and Aksoy, H. (2008): Effect of exogenous GnRH at the time of artificial insemination on reproductive performance of Awassi ewes synchronized with progestagenPMSG-PGF2 $\alpha$ combination. Reprod. Domest. Anim. 43, 308-313.

Uhm, S.J.; Gupta, M.K. and Yang, Jr.H. (2007): Embryo development: Selenium improves the developmental ability and reduces the apoptosis in porcine parthenotes. Mol. Reprod. Dev., 74: 386-1394.

Wilkins, J.F. (1997): Method of stimulating ovulation rate in Merino ewes may affect conception but not embryo survival. Anim. Reprod. Sci., 47: 31-42.

Wittwer, F.; Araneda, P. and Ceballos, A. (2002): Actividad de glutation peroxidase (GSH-Px) en sangre de bovinos a pastoreo de la IX región, Chile y su relación con la concentración de selênio en el forraje. Arch. Med. Vet., v.34, p.1-10.

Zeleke, M.; Greling, J.P.C.; Schwalbach, L.M.J. and Erasmus, J.A. (2005): Effect of progestagen and PMSG on oestrous synchronization and fertility in Dorper ewes during the transition period. Small Ruminant Research 56(1): 47-53.

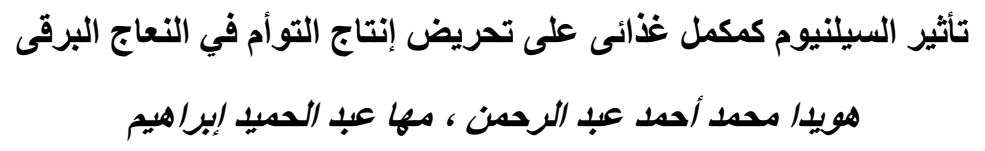

E-mail: maha_doctor2013@yahoo.com Assiut University web-site: www.aun.edu.eg

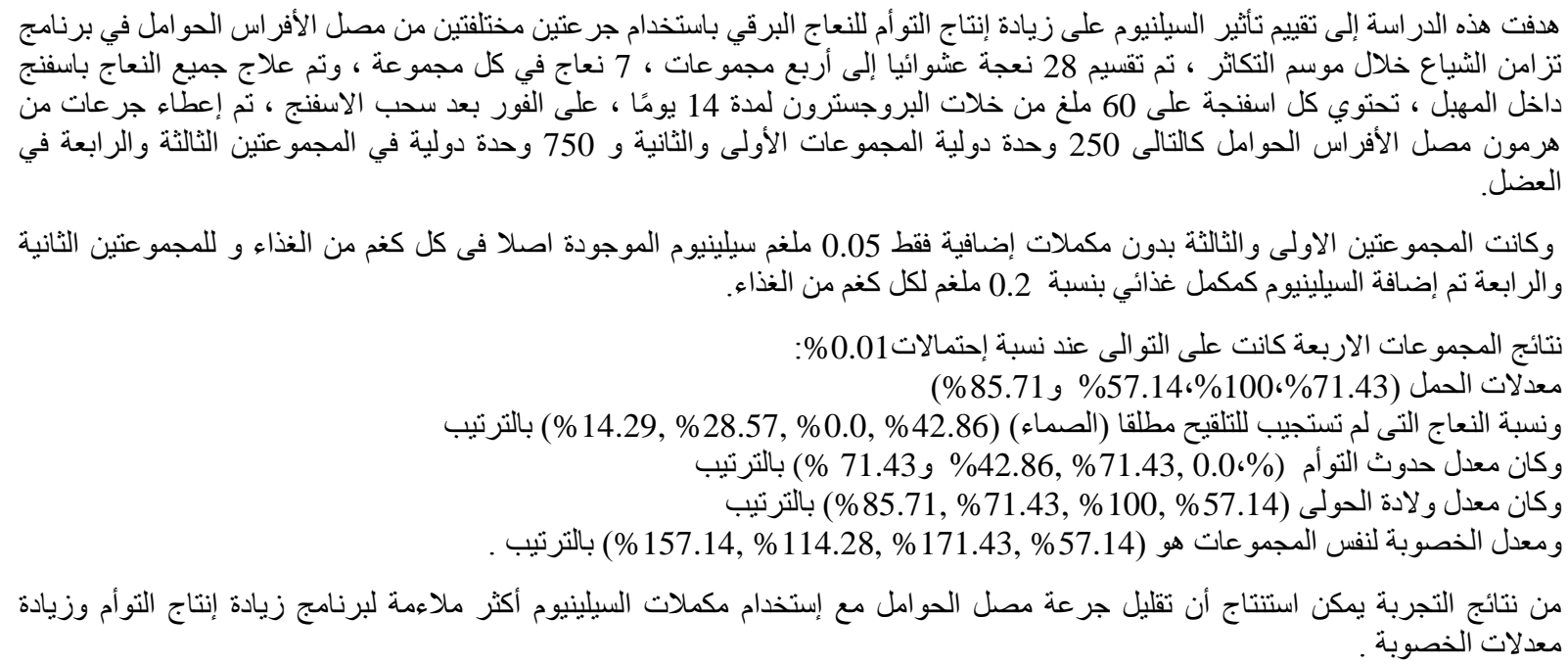

